\title{
Factors Influencing Individual Customers Trust in Internet Banking: Case of Baltic States
}

\author{
Viktorija Skvarciany * *il and Daiva Jurevičienè \\ Department of Economics Engineering, Faculty of Business Management, Vilnius Gediminas Technical \\ University, 10223 Vilnius, Lithuania; daiva.jureviciene@vgtu.lt \\ * Correspondence: viktorija.skvarciany@vgtu.lt
}

Received: 5 November 2018; Accepted: 30 November 2018; Published: 17 December 2018

\begin{abstract}
The investigation of trust in commercial banks needs to focus specifically on internet banking, as it is the fastest growing banking service. The article explores factors influencing trust in internet banking and estimates this impact in the Baltics states. The factors are as follows: Provided information, e-banking system, the website of a bank, and a bank's characteristics. Overall, 1013 respondents and 21 experts took part in the current study. The results of the respondents' survey showed that the factor that is necessary for trust building in all the examined countries differs: In Lithuania, information and the bank, in Latvia, the website, and in Estonia, the bank. According to the experts, the most powerful factor in the trust-building process in Lithuania and Latvia is the e-banking system while in Estonia, the website. The research has the following limitations: The online survey of individual customers (however, internet banking relates to internet users, so this limitation is not essential); the analysis of only the positively affecting criteria of the trust-building process; only experts assessed the subfactors.
\end{abstract}

Keywords: internet banking; trust; individual customers; Baltic States

\section{Introduction}

Customer trust is one of the factors that are analysed by scientists and business analysts. Trust is being investigated as the antecedent of customers' loyalty and satisfaction, the background of corporate social responsibility (CSR), the part of business ethics determinants, etc. Commercial banks are not an exception, and trust is one of the drivers of clients' attraction. Regarding banking, internet banking is one of the most popular services provided by commercial banks, and e-banking has a positive impact on the performance of banks [1]. Keskar and Pandey [2] wrote a review of the articles (51 papers) exploring internet banking topics and published in 2002-2016. Their study showed that trust had been extensively studied as an important factor influencing the adoption and use of internet banking. Therefore, internet-banking acceptance by clients is one of the essential factors in the success of the overall commercial bank's activities. What is more, internet banking is a crucial factor for e-society development [3] that is necessary for the digitalisation processes of the economy taking place in the world. Internet banking is attractive to customers as it helps to reduce costs, control transactions, waiting times, etc. [4]. Thus, there are a lot of benefits provided by internet banking, but despite that fact, scholars agree that one of the essential factors in internet banking adoption is trust [5-9]. Lack of trust in banks is a common determinant of bank runs, so the factors shaping confidence are a prime concern for bank regulators [10]. Alghamdi, Elbeltagi, Elsetouhi, and Haddoud [11] research illustrated that psychological traits are vital in influencing the processes of cognitive perception that, in turn, influence usage intentions. Moreover, trust has a positive impact on customers' and internet banking relationship in a long-term perspective [12]. 
In general, trust in information and communication technology affects the adoption of information and communication technologies. Additionally, information and communication technologies may promote trust while they allow faster and more reliable acquisition of information and support transparency [13].

This article explores what factors lead customers to trust internet banking. An analysis of related literature shows that sometimes, scholars examine trust as an outcome of other features, sometimes as a contributor to a specific element. In this article, we analyse the system of trust-influencing factors and then subfactors that affect those factors. The assessment of the defined criteria of trust in internet banking allows to determine the most important ones for a particular market. The evaluation will help decision-makers to increase trust and extend the use of internet banking services. The investigation of defined factors was made in Lithuania, Latvia, and Estonia.

Consequently, the object of the research was the factors influencing individual customers' trust in internet banking. The goal of the research was to test the impact of factors on trust empirically via the created model of customers' trust in internet banking. After analysing and summarising previous researches, the most important factors influencing customers' trust in internet banking were distinguished; a theoretical model for measuring the importance of factors in the trust-building process was created. The methodology was then detailed, and research in the Baltic States tested the created model that assess customers' trust in internet banking. The methods used in the research were: Scientific literature analysis and systematisation; respondents' survey (questionnaire) and expert evaluation method for data collection; logistic regression and the analytic hierarchy process for assessment of factors. Two methods for data collection were used in order to have a comprehensive view and to compare the obtained results.

However, there were a few research limitations. The residents survey was conducted in cyberspace; therefore, the results are applicable only to internet users. However, as the topic of the research is the assessment of customers' trust in internet banking, this limitation is not essential. The second limitation was that all the analysed factors and subfactors increased the level of individual customers' trust in commercial banks. The factors that could decrease the level of trust were not analysed in the current study. The third was that only experts assessed the subfactors.

\section{Theoretical Background}

Many studies dealing with the relationship between trust and intention to use online banking services have been conducted in the past few years. In fact, many scientists argue that trust has a direct positive impact on the consumer's intention to use e-banking [9,14-21]. What is more, trust is a determining factor, leading to further use of online banking. As trust is an important issue in defining the success of e-banking, it is important to determine what leads to a higher level of trust [22].

Some researchers say that satisfaction is one of the essential elements that affect customer trust in online banking [23-25]. By studying online banking, they noticed that customer satisfaction leads to trust in online banking services. After an investigation of trust, internet banking researchers found out that satisfaction is one of the most critical factors, contributing to increasing trust in the banking cyberspace [26]. Moreover, the perceived benefits of online banking have a positive effect on consumer trust [24]. In addition, internal motivation positively affects consumers' trust in online banking [27]. Fairness is distinguished as a factor, which affects consumer trust positively as well [28]. Trust in online banking leads to perceived security, privacy, benefits of online banking, and ease of use of the website [24]. Ease of use and accessibility of the e-banking site are also mentioned as trust-generating factors [29]. The following factors are identified behind the formation of trust: Benevolence, competence, integrity, and common values. Integrity is the bank's interest in the client's well-being [30]. What is more, a significant relationship between trust and perceived risk exists [31]. Moreover, both trust and perceived risk are factors, explaining the client's intention to use e-banking services [32]. The results of Siriluck and Speece's [33] study showed that the quality of information, access to information, and the advantages of web-based trading services positively affect the strength 
of the connection between the customers and the banks. The following factors determining the initial appearance of trust in internet banking were identified in the scientific literature: The relative benefits, perceived privacy, perceived security, site usability, and reputation [34].

The results of Patel and Patel's [35] investigation highlighted that the intention to use internet banking is positively influenced mainly by the perceived security, followed by other significant factors, namely, perceived usefulness, perceived ease of use, and social influence [35]. The results of Namahoot and Laohavichien's [36] research showed that the service quality, perceived risk, and trust influence behavioural intentions to use internet banking. Their study primarily aimed to find out whether perceived risk and trust worked as a mediator variable between service quality and behavioural intentions to use internet banking [36].

Lee and Moghavvemi [37] found there was a positive relationship between clients' trust and the bank's image, that is, the image influences the level of trust. Chemingui and Ben lallouna [38] argue that the quality of the mobile banking system has a positive impact on consumer confidence and the system quality has a significant and positive impact on trust in mobile service providers.

The results of the Pandey, Mayya, and Joshi's [39] study indicated that perception and driving factors are essential for customers to adopt internet banking together with customers' knowledge, security, and privacy, which play vital role in adopting any new technology. A habit of using traditional ways of banking and feeling of "no need to use internet banking" also influences customers' aspiration to adopt internet banking [39].

The Kaabachi, Mrad, and Petrescu [40] study on internet-only banks highlighted that consumers' familiarity with internet banking, high-perceived structural assurance, perceived website quality, bank reputation, and relative advantage are critical factors influencing internet-only banks' initial trust formation [40]. It is worth noting that the perceived website quality was found to be the strongest predictor of initial trust. In addition, they proved that information quality would act as a trust signal for customers and stated that internet-only banks should provide relevant and accurate information about their security and privacy issues via their website. There results made for internet-only banks are applicable to all banks' internet services, i.e., banks need to focus on making themselves known and promoting their brand more effectively.

The data obtained by Casaló, Flavián, and Guinalíu [16] showed that website security and privacy, usability, and reputation have a direct and significant effect on consumer trust in a financial services website. In addition, consumer trust is positively related to relationship commitment. Finally, it was observed that trust was a critical mediating factor in the development of a relationship commitment in the online banking context [16]. According to Hajiheydari and Ashkani [41], perceived usefulness refers to an individual's understanding of whether new technology could facilitate the objective of an activity. Perceived ease of use is defined as the degree of ease an individual expects from new technology in order to use it with minimum effort and based on his/her current skills and knowledge.

All the findings mentioned earlier show the importance of trust in the context of banking services and is a significant player in promoting internet banking services as well as attracting new customers. The mentioned criteria related to trust building are summarised in Table 1.

Table 1. Summary of trust in internet banking related criteria ascertained by authors.

\begin{tabular}{|c|c|c|}
\hline $\begin{array}{c}\text { Criterion } \\
\text { (Name of Equivalent Used } \\
\text { by Authors) }\end{array}$ & Publication & Factors Highlighted in Literature \\
\hline Transparency & [40] & Relevant and accurate \\
\hline Reliability & {$[31,32,36,42]$} & Perceived risk \\
\hline Quality & {$[33,40]$} & \\
\hline Competence & {$[30]$} & \\
\hline Goodwill & {$[30]$} & Benevolence \\
\hline Reputation & {$[16,34,40]$} & \\
\hline Integrity & {$[16,30]$} & Relationship commitment \\
\hline
\end{tabular}


Table 1. Cont.

\begin{tabular}{|c|c|c|}
\hline $\begin{array}{c}\text { Criterion } \\
\text { (Name of Equivalent Used } \\
\text { by Authors) }\end{array}$ & Publication & Factors Highlighted in Literature \\
\hline $\begin{array}{l}\text { Shared Values } \\
\text { Image }\end{array}$ & $\begin{array}{c}{[30]} \\
{[37,40]}\end{array}$ & Common value \\
\hline Security & {$[16,24,34,35,39,40]$} & $\begin{array}{l}\text { Perceived security, perceived website } \\
\text { quality }\end{array}$ \\
\hline Ease of use & {$[16,24,29,35,41]$} & $\begin{array}{l}\text { Accessibility, perceived ease of use, } \\
\text { convenience }\end{array}$ \\
\hline Privacy & {$[16,24,34,39]$} & Perceived privacy \\
\hline Perceived benefits & {$[24,34,35,40,41]$} & $\begin{array}{c}\text { Relative benefits, perceived usefulness, } \\
\text { comparative Advantage, perceived } \\
\text { usefulness }\end{array}$ \\
\hline Clients' internal motivation & {$[27,32,39]$} & $\begin{array}{l}\text { Intention to use, habit of using traditional } \\
\text { ways }\end{array}$ \\
\hline $\begin{array}{l}\text { Satisfaction with system } \\
\text { fairness }\end{array}$ & $\begin{array}{c}{[36,43]} \\
{[28]}\end{array}$ & $\begin{array}{c}\text { Service quality, system quality } \\
\text { Fairness }\end{array}$ \\
\hline
\end{tabular}

For a more natural understanding, the selected criteria affecting trust in internet banking were divided into four groups (factors) and their subgroups (subfactors) (see Figure 1).

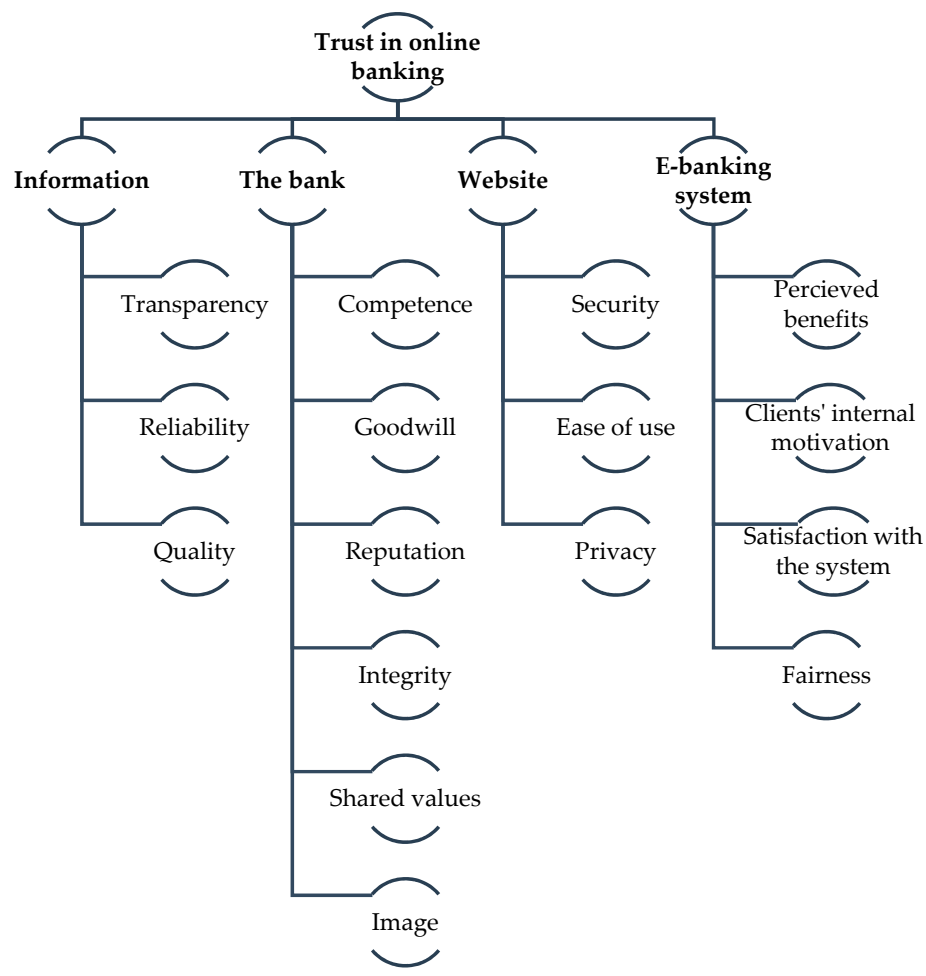

Figure 1. Research model on factors and subfactors having an impact on trust in internet banking (developed by authors based on Table 1).

All these factors-information, the bank, website and e-banking system-and their subfactors were assessed in Lithuania, Latvia, and Estonia. Residents evaluated only the main factors, while experts assessed both factors and subfactors. All the factors and subfactors were found to increase the level of individual customers' trust in commercial banks, but they have the various impacts in these countries and they were assessed differently by residents and by experts. 


\section{Methodology}

In order to get reliable research results, two types of respondents were questioned, i.e., residents of three Baltic countries and experts from the same countries. In order to gather the information, a residents' and experts' survey was conducted.

The residents' survey was implemented in order to get Lithuania's, Latvia's, and Estonia's residents' views on factors that influence individual customers' trust in internet banking. The number of respondents in the residents' survey was calculated using the following formula:

$$
n=\frac{N \times\left(Z_{\alpha / 2}^{2} \times p \times(1-p)\right) / \Delta^{2}}{\left(Z_{\alpha / 2}^{2} \times p \times(1-p)\right) / \Delta^{2}+N-1},
$$

where:

n-sample size;

$\mathrm{N}$-population size;

$Z_{\alpha / 2}$-critical value of normal distribution at $\alpha / 2$;

$p$-sample proportion;

$\Delta$-margin of error.

For the present research, the margin of error was equal to $0.05(\Delta=0.05)$, confidence level was $90 \%$, and the sample proportion equal to $50 \%(p=50 \%)$.

Expert judgement was used in order to get experts' points of view not only on factors influencing individual customers' trust in internet banking, but also on their subfactors. The number of experts was determined to refer to Libby and Blashfield [44], who claim that the reliability of the results generated by the group of five experts exceeds the 75 per cent threshold. The number of experts in the current study is 21 , i.e., 7 experts from each country.

In order to get reliable research results, an appropriate number of experts was not the only indicator to be applied. It is necessary to examine the competence of the experts. For this purpose, the following formulas were used [45]:

$$
\begin{gathered}
K_{i}^{0}=\frac{1}{m}, j=1, \ldots, m, \\
x_{j}^{t}=\sum_{i=1}^{m} K_{i}^{t-1} x_{i j}, j=1, \ldots, k \\
\lambda^{t}=\sum_{j=1}^{k} \sum_{i=1}^{m} x_{j}^{t} x_{i j} \\
K_{i}^{t}=\frac{1}{\lambda^{t}} \sum_{j=1}^{k} x_{j}^{t} x_{i j}, \sum_{i=1}^{m} K_{i}^{t}=1
\end{gathered}
$$

where:

$m$-number of experts;

$k$-number of alternatives;

$K_{i}^{t}$-coefficient of an expert's competence.

If the calculated coefficients fall within an interval $\bar{K}_{i}^{t}-1.96 s \leq K_{i}^{t} \leq \bar{K}_{i}^{t}+1.96 s$, where $\bar{K}_{i}^{t}$ stands for the mean of competence coefficients and $s$ is standard deviation, the competence of the experts is proved. 
What is more, a measure of internal consistency of a scale—Cronbach's alpha—was calculated [46]:

$$
\text { Cronbach's } \alpha=\frac{k}{k-1}\left(1-\frac{\sum s_{i}^{2}}{s_{T}^{2}}\right)
$$

where:

$k$-number of alternatives;

$s_{i}^{2}$-variance of $i$-th alternative;

$s_{T}^{2}$-variance of total score formed by summing all the alternatives.

For the collected data analysis, logistic regression and AHP method were used. The description of the chosen methods is presented below.

\subsection{Logistic Regression}

For an assessment of factors influencing individual customers' trust in internet banking, a logistic (logit) regression was used. Usually, scholars use regression analysis in order to investigate the trust phenomenon [47-49]. Actually, one of the regression models that are used is a logistic regression. Logistic regression is a powerful tool that could be used for examining socioeconomic factors if the relationship between variables is not linear [50]. Logistic regression parameters are estimated through maximum likelihood, and it returns the probability of an examined event within a logistic model [51]. The model of multiple logistic regression is presented below (7) [52]:

$$
\ln \left(\frac{\mathbb{P}(Y=1)}{\mathbb{P}(Y=0)}\right)=\beta_{0}+\sum_{i=1}^{n} \beta_{i} x_{i}
$$

where:

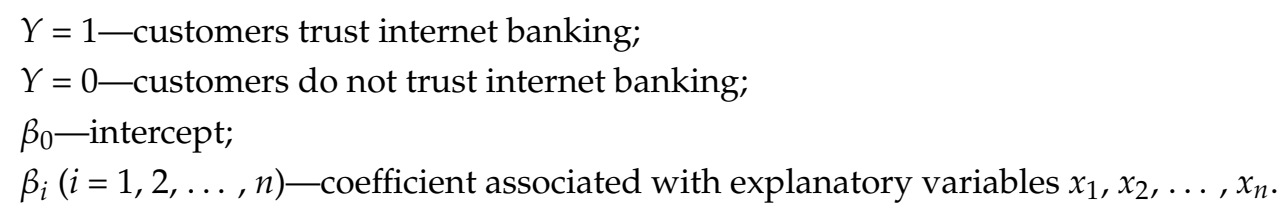

In order to test the statistical adequacy and quality of the logistic model Contingency table test, Nagelkerke pseudo- $R^{2}$, Pearson chi-square test, and Wald test were used. The contingency table verifies the distribution of each independent variable; Nagelkerke pseudo- $\mathrm{R}^{2}$ is the quality indicator that assesses the goodness-of-fit of the proposed model (the model is acceptable if Nagelkerke pseudo- $\mathrm{R}^{2}>0.15$ ); the Pearson chi-square test shows whether the model is suitable for the description of the dependent variable (the model is acceptable if $p \geq 0.05$ ); the Wald test examines whether the coefficients $\beta_{i}$ of the individual logistic regression equations are statistically significant (the coefficients are significant if $p<0.05$ ) [53-58].

In the current research, the logistic regression is applied in order to understand which value of the dependent variable $(Y)$ is more likely to occur when the specific category variable is selected. The dependent variable $Y$ can obtain values between 0 and 1 , where $Y=0$ means that customers do not trust internet banking, while $Y=1$ means that individual clients of a commercial bank do trust internet banking. The respondents' age was marked as a categorical variable that could gain a value of 0 and 1 , where 0 means that the respondent is 35 years old or younger and 1 means that the respondent is older than 35 years old. The age of the respondents was chosen as a categorical variable, as young people are more likely to adopt such innovations as e-banking than older ones.

\subsection{AHP Method}

In order to rank the factors and their subfactors, the pairwise comparison method was used. The results of the experts' pairwise comparison were obtained using the analytic hierarchy process 
(AHP). For alternative ranking, a balanced scale was used, as according to the developers it improves the sensitivity of relative scales of AHP [59]. The balanced scale's parameters are presented in Table 2 .

Table 2. Balanced scale used in the survey [59].

\begin{tabular}{cccc}
\hline $\begin{array}{c}\text { Type of } \\
\text { Scale }\end{array}$ & $\begin{array}{c}\text { Mathematical } \\
\text { Expression }\end{array}$ & Parameters & Approximate Scale Values \\
\hline Balanced & $s=\frac{1}{1-w}$ & $w=\{0.5 ; 0.55 ; 0.6 ; \ldots ; 9\}$ & $1 ; 1.22 ; 1.5 ; 1.86 ; 2.33 ; 3 ; 4 ; 5.67 ; 9$ \\
\hline
\end{tabular}

The methodology of AHP could be explained in several steps:

Step 1: Experts/judges compare alternatives $\left\{\theta_{1}, \ldots, \theta_{n}\right\}$ with each other by completing pairwise comparison matrices $A=\left(\alpha_{i j}\right)_{n \times n}$, where $a_{i j}=\frac{\omega_{i}}{\omega_{j}}, \forall i, j=1,2, \ldots, n ; \omega_{n}(n=1,2, \ldots, n)$-priority vector; $a_{i j}=\frac{1}{a_{i j}}, \forall i, j=1,2, \ldots, n$.

Step 2: All the experts' assessments are written in a standardised matrix form, and an arithmetic mean of each line is calculated to identify the main factor.

Step 3: The consistency of each matrix is verified. A pairwise comparison matrix is considered consistent if there is a priority vector $w=\left(\omega_{1}, \ldots, \omega_{n}\right)$ that $a_{i j}=\frac{\omega_{i}}{\omega_{j}}, \forall i, j$. The consistency of each expert assessment is evaluated using the consistency index (CI) [60]. For the consistency index determination, an eigenvalue of the pairwise comparison matrix is computed. A comparison matrix is considered to be consistent if $\lambda_{\max }=n$ or close to $n$. Since the value of $\lambda_{\max }$ is computed, consistency index $C I$ is calculated: $C I=\left(\lambda_{\max }-n\right) /(n-1)$. Then, the consistency ratio $(C R)$ is calculated by dividing the consistency ratio by the random index. The values of the consistency ratio depend on matrix order $m$. In the current study, the matrices orders are 3,4 , and 6 . Hence, values of the random index are $0.58,0.9$, and 1.24 , respectively [61].

Step 4: The aggregated judges' assessment is calculated for the consistent matrices $(C R<0.2)$ using the geometric mean method.

Step 5: The aggregated matrix consistency checking procedure is performed. If the matrix is consistent, the priorities of the factors and their subfactors are computed using the normalized geometric mean method (8) [62]:

$$
\omega_{j}=\frac{\sqrt[i]{\prod_{j=1}^{i} a_{i j}^{A}}}{\sum_{j=1}^{i} \sqrt[i]{\prod_{j=1}^{i} a_{i j}^{A}}}
$$

where: $\omega_{j}$-weight of $j$ alternative.

Moreover, the judges' consensus index [63] is calculated (9).

$$
S^{*}=\frac{\frac{1}{\exp \left(H_{\beta}\right)}-\frac{\exp \left(H_{\text {main }}\right)}{\exp \left(H_{\gamma \max }\right)}}{1-\frac{\exp \left(H_{\alpha \min }\right)}{\exp \left(H_{\gamma \max }\right)}}
$$

where:

$S^{*}$ - consensus index;

$H_{\alpha}$-Shannon alpha diversity;

$H_{\beta}$-Shannon beta diversity;

$H_{\gamma}$-Shannon gamma diversity.

The index value varies from 0 to 100 per cent and shows the level of agreement between the judges. 


\section{Empirical Findings}

\subsection{Results of Logistic Regression Analysis Based on Respondents' Survey}

The overall number of answers received from the residents of the Baltic States was 1030, however, some of them were removed from further analysis according to the inappropriate filling in the questionnaire (e.g. the questionnaire was incomplete or the respondent marked he did not use Internet banking). Hence, the number of respondents in the researched countries was as follows: In Lithuania-342; in Latvia-351; in Estonia-320. The minimum size of samples for each country was calculated using Equation (1) and reached 271 respondents. In the current study, the sample size of each country was higher, which demonstrated that the results represented the whole country's population.

Respondents had to fill in a questionnaire and assess the most important factors for them.

The study was conducted in cyberspace using the website www.manoapklausa.lt [64], developed by "Solid Data", UAB. Actually, as the research was done online, there was a limitation-the results could be applied only to internet users.

While analysing trust in internet banking $(\mathrm{Y})$, respondents were asked to evaluate the influence of the following factors on their trust:

- $\quad$ Provided information, $X_{1}$

- $\quad$ E-banking system, $X_{2}$

- Website of a bank, $X_{3}$

- $\quad$ The bank's characteristics, $X_{4}$.

For the purpose of assessment of individual customers' trust in internet banking, logistic regression was used. The respondents' age was selected as a categorical variable. Overall, $87 \%$ of the participants in Lithuania in the cross-validation group were correctly classified; in Latvia, this number reached $84.1 \%$, whereas in Estonia $86.3 \%$. Nagelkerke pseudo- $\mathrm{R}^{2}$ in Lithuania, Latvia, and Estonia was $0.291,0.518$, and 0.243 , respectively. All the values were greater than 0.15 , which means that the model is acceptable and could explain populations' intentions on whether to trust internet banking. The model's $\chi^{2}$ in Lithuania was 63.145, in Latvia 149.684, and in Estonia 49.491, which means that in all the cases, $\chi^{2}$ satisfied the condition $p<0.01$. What is more, according to the Wald test, statistically insignificant variables were removed from the analysis. They were as follows: $X_{2}$ (e-banking system), $\mathrm{X}_{3}$ (website of a bank) in Lithuania; $\mathrm{X}_{1}$ (provided information) in Latvia; and $\mathrm{X}_{1}$ (provided information), $\mathrm{X}_{2}$ (e-banking system), $\mathrm{X}_{3}$ (website of a bank) in Estonia. The not mentioned variables satisfied the Wald criterion and were used for the logistic regression models' development (see Table 3).

Table 3. Logistic models of the factors influencing individual customers trust in internet banking (authors' calculations based on residents' survey).

\begin{tabular}{cl}
\hline Country & Logistic Regression Model \\
\hline Lithuania & $\ln \frac{\hat{\mathbb{P}}\left(Y_{L T}=0\right)}{\hat{\mathbb{P}}\left(Y_{L T}=1\right)}=9.740-2.719 X_{1}-2.275 X_{4}+\left\{\begin{array}{l}2.146, \text { if } X_{\text {cat }}=0, \\
0, \text { if } X_{\text {cat }}=1 .\end{array}\right.$ \\
\hline Latvia & $\ln \frac{\hat{\mathbb{P}}\left(Y_{L V}=0\right)}{\hat{\mathbb{P}}\left(Y_{L V}=1\right)}=16.851-1.852 X_{2}-2.587 X_{3}-1.480 X_{4}+\left\{\begin{array}{c}-0.134, \text { if } X_{\text {cat }}=0, \\
0, \text { if } X_{\text {cat }}=1 .\end{array}\right.$ \\
\hline Estonia & $\ln \frac{\hat{\mathbb{P}}\left(Y_{E E}=0\right)}{\hat{\mathbb{P}}\left(Y_{E E}=1\right)}=3.489-1.924 X_{4}+\left\{\begin{array}{c}-0.134, \text { if } X_{\text {cat }}=0, \\
0, \text { if } X_{\text {cat }}=1 .\end{array}\right.$ \\
\hline
\end{tabular}

As was mentioned above, the respondents' age was selected as a categorical variable $\left(X_{\text {cat }}\right)$ that could gain a value of 0 and 1 ( 0 means that the respondent is 35 years old or younger, 1 means that the respondent is older than 35 years old). From Equation developed for Lithuania, it could be seen that in the case of Lithuania, the greater the values of regressors $X_{1}$ (provided information) and $\mathrm{X}_{4}$ (the bank's characteristics) were, the higher the probability that individual customer trusts/will 
trust internet banking. In other words, the more transparent, qualitative, and reliable the provided information is, the higher the level of characteristics of a bank, such as its image and reputation, and the higher individual clients' trust in internet banking in Lithuania. The odds ratio estimates and their $90 \%$ confidence level are as follows: For the regressor $X_{1}$ (provided information) 0.066 ([0.04; $1.160]$ ) and for the regressor $X_{4}$ (the bank's characteristics) 0.103 ([0.10; 1.055]). According to Equation developed for Latvia's residents, it could be claimed that e-banking system, the website of a bank, and the characteristics of a bank are the factors that enhance the probability of individual customers' trust in internet banking in Latvia. The odds ratio estimates and their $90 \%$ confidence levels were as follows: For the regressor $X_{2}$ (e-banking system) 0.157 ([0.43; 0.578]), for the regressor $X_{3}$ (website of a bank) 0.075 ([0.15; 0375]), and for the regressor $X_{4}$ (the bank's characteristics) 0.228 ([0.056; 0.924]). Analysing Equation designed using Estonia's respondents' answers, it became clear that the characteristics of a bank are the only factors that help to increase the probability of trust in internet banking. The odds ratio estimates and their $90 \%$ confidence levels were as follows: For the regressor $\mathrm{X}_{1}$ (provided information) 0.146 ([0.070; 0.305]).

\subsection{Results of AHP Analysis Based on Expert Evaluation}

In order to calculate the weights of the selected factors and subfactors influencing individual customers' trust in internet banking, seven experts from each country were selected. All the experts held $\mathrm{PhD}$ degrees in economics/management/finance and had at least three years working experience in the field of banking. Information about the experts is presented in Table 4.

Table 4. Qualitative information about experts (designed by authors).

\begin{tabular}{|c|c|c|c|c|c|}
\hline $\begin{array}{l}\text { Expert } \\
\text { Code }\end{array}$ & $\begin{array}{l}\text { Information about } \\
\text { Experts (Lithuania) }\end{array}$ & $\begin{array}{l}\text { Expert } \\
\text { Code }\end{array}$ & $\begin{array}{l}\text { Information about } \\
\text { Experts (Latvia) }\end{array}$ & $\begin{array}{l}\text { Expert } \\
\text { Code }\end{array}$ & $\begin{array}{l}\text { Information about } \\
\text { Experts (Estonia) }\end{array}$ \\
\hline $\mathrm{E}_{\mathrm{LT} 1}$ & $\begin{array}{c}\text { PhD in management; } \\
\text { working experience-9 } \\
\text { years }\end{array}$ & $\mathrm{E}_{\mathrm{LV} 1}$ & $\begin{array}{c}\text { PhD in economics; } \\
\text { working experience-8 } \\
\text { years }\end{array}$ & $\mathrm{E}_{\mathrm{EE} 1}$ & $\begin{array}{l}\text { PhD in business } \\
\text { management and } \\
\text { marketing; working } \\
\text { experience-22 years }\end{array}$ \\
\hline $\mathrm{E}_{\mathrm{LT} 2}$ & $\begin{array}{c}\text { PhD in business } \\
\text { administration; working } \\
\text { experience-22 years }\end{array}$ & $\mathrm{E}_{\mathrm{LV} 2}$ & $\begin{array}{c}\text { PhD in economics; } \\
\text { working experience-10 } \\
\text { years }\end{array}$ & $\mathrm{E}_{\mathrm{EE} 2}$ & $\begin{array}{c}\text { PhD in economics; } \\
\text { working experience-18 } \\
\text { years }\end{array}$ \\
\hline $\mathrm{E}_{\mathrm{LT3}}$ & $\begin{array}{l}\text { PhD in management; } \\
\text { working experience-10 } \\
\text { years }\end{array}$ & $\mathrm{E}_{\mathrm{LV} 3}$ & $\begin{array}{c}\text { PhD in economics; } \\
\text { working experience-15 } \\
\text { years }\end{array}$ & $\mathrm{E}_{\mathrm{EE} 3}$ & $\begin{array}{c}\text { PhD in econometrics; } \\
\text { working experience-19 } \\
\text { years }\end{array}$ \\
\hline $\mathrm{E}_{\mathrm{LT} 4}$ & $\begin{array}{l}\text { PhD in marketing } \\
\text { management; working } \\
\text { experience-34 years }\end{array}$ & $\mathrm{E}_{\mathrm{LV} 4}$ & $\begin{array}{c}\text { PhD in business } \\
\text { administration; working } \\
\text { experience- } 5 \text { years }\end{array}$ & $\mathrm{E}_{\mathrm{EE} 4}$ & $\begin{array}{c}\text { PhD in economics; } \\
\text { working experience-14 } \\
\text { years }\end{array}$ \\
\hline $\mathrm{E}_{\mathrm{LT} 5}$ & $\begin{array}{l}\text { PhD in economics; } \\
\text { working experience-25 } \\
\text { years }\end{array}$ & $\mathrm{E}_{\mathrm{LV} 5}$ & $\begin{array}{c}\mathrm{PhD} \text { in management; } \\
\text { working experience-4 } \\
\text { years }\end{array}$ & $\mathrm{E}_{\mathrm{EE} 5}$ & $\begin{array}{c}\text { PhD in economics; } \\
\text { working experience-9 } \\
\text { years }\end{array}$ \\
\hline $\mathrm{E}_{\mathrm{LT} 6}$ & $\begin{array}{c}\text { PhD in economics; } \\
\text { working experience-4 } \\
\text { years }\end{array}$ & $\mathrm{E}_{\mathrm{LV} 6}$ & $\begin{array}{c}\text { PhD in economics; } \\
\text { working experience-7 } \\
\text { years }\end{array}$ & $\mathrm{E}_{\mathrm{EE} 6}$ & $\begin{array}{c}\text { PhD in management; } \\
\text { working experience-4 } \\
\text { years }\end{array}$ \\
\hline $\mathrm{E}_{\mathrm{LT7}}$ & $\begin{array}{c}\text { PhD in economics; } \\
\text { working experience-18 } \\
\text { years }\end{array}$ & $\mathrm{E}_{\mathrm{LV} 7}$ & $\begin{array}{l}\text { PhD in business } \\
\text { management; working } \\
\text { experience-10 years }\end{array}$ & $\mathrm{E}_{\mathrm{EE} 7}$ & $\begin{array}{l}\mathrm{PhD} \text { in communication } \\
\text { management; working } \\
\text { experience-8 years }\end{array}$ \\
\hline
\end{tabular}

It is worth mentioning that the competence coefficient was calculated for all the experts (see Appendix A). All the results fell into the interval $\bar{K}_{i}^{t}-1.96 s \leq K_{i}^{t} \leq \bar{K}_{i}^{t}+1.96 s$, where s varies between 0.003 and 0.005 for the countries analysed. Hence, it could be stated that there were no outliers in the experts' answers and all the results might be used for the trust in internet banking factors and their subfactor prioritisation. Moreover, the results of Cronbach's alpha indicate a high level of consistency (Cronbach's $\alpha=0.783$ ). Consequently, the weight of each alternative could be calculated. 
Since the weights of each alternative/factor were computed, the most vital factor was identified.

Experts assessed four determinants of individuals' trust in internet banking: Information; the bank; website; e-banking system.

Studying Lithuania's, Latvia's, and Estonia's experts' pairwise comparison matrices, it became obvious that the matrices of the experts coded $\mathrm{ET}_{\mathrm{LT} 3}$ and $\mathrm{ET}_{\mathrm{EE} 2}$ were inconsistent and before aggregating the final result matrices, they were modified into consistent ones using Method-S, presented in the Methodology section. Other experts' matrices met the condition $\mathrm{CR}<0.2$ and did not need modifications.

Lithuanian and Latvian experts highlighted the electronic banking system as a factor having the greatest impact on the confidence in internet banking (see Table 5). The bank site ranked first, while the e-banking system remained the second according to Estonian experts. However, the difference between these factors is minimal, so it can be said that they are almost equivalent.

Table 5. Weight of factors influencing individual customers' trust in internet banking (authors' calculations, based on experts' assessment).

\begin{tabular}{cccc}
\hline \multirow{2}{*}{ Factor } & \multicolumn{3}{c}{ Weight (Rank) } \\
\cline { 2 - 4 } & LT & LV & EE \\
\hline Information & $0.206(4)$ & $0.112(4)$ & $0.191(3)$ \\
The bank & $0.265(2)$ & $0.167(3)$ & $0.159(4)$ \\
Website & $0.205(3)$ & $0.354(2)$ & $0.328(1)$ \\
E-banking system & $0.324(1)$ & $0.367(1)$ & $0.323(2)$ \\
\hline \multicolumn{4}{c}{ Technical Parameters } \\
\hline$\lambda ;$ CR; $\mathrm{S}^{*}$ & $4.116 ; 0.043 ; 77.7 \%$ & $4.038 ; 0.014 ; 73.3 \%$ & $4.034 ; 0.016 ; 76.6 \%$ \\
\hline
\end{tabular}

In the theoretical part, subfactors were identified for each factor of confidence in internet banking. Experts also assessed them. The analysis of Lithuanian experts' subfactors pairwise comparison matrices revealed that the individual matrix compatibility ratio of experts coded $\mathrm{ET}_{\mathrm{LV} 1,3}, \mathrm{ET}_{\mathrm{EE} 5}$ was greater than 0.2 , so it can be said that the matrix was inconsistent and before the overall assessment needed to be harmonised. Other experts' pairwise comparison matrices compatibility indices were in line with the initial condition, i.e., $C R<0.2$. The compatibility ratio and lambda $(\lambda)$ complied with the conditions laid down, so it can be concluded that the experts' evaluation is accurate (see Table 5). In addition, the consensus (agreement) index was greater than 80 per cent in all the investigated countries (see Table 5). Thus, as can be seen from Table 5, the criteria used to assess the accuracy of experts' opinions is satisfied; therefore, it can be said that the weights given by experts are significant. The weights and ranks of subfactors are presented in Table 6.

Table 6. Weights of information subfactors (authors' calculation, based on experts' assessment).

\begin{tabular}{cccc}
\hline \multirow{2}{*}{ Subfactor } & \multicolumn{3}{c}{ Weight (Rank) } \\
\cline { 2 - 4 } & LT & LV & EE \\
\hline Transparency & $0.253(3)$ & $0.293(3)$ & $0.289(2)$ \\
Quality & $0.281(2)$ & $0.343(2)$ & $0.265(3)$ \\
Reliability & $0.466(1)$ & $0.364(1)$ & $0.445(1)$ \\
\hline \multicolumn{4}{c}{ Technical Parameters } \\
\hline$\lambda ; \mathrm{CR}^{*} \mathrm{~S}^{*}$ & $3.002 ; 0.002 ; 89.1 \%$ & $3.005 ; 0.006 ; 90.0 \%$ & $3.012 ; 0.013 ; 93.1 \%$ \\
\hline
\end{tabular}

Lithuanian, Latvian, and Estonian experts' opinions on the most important subfactors of information are the same (see Table 6). Baltic experts agreed that reliability is the most important subfactor, and experts of all the countries ranked it as the first and gave it greater than 0.36 weight. 
Lithuanian and Latvian experts considered the quality of information as the next major factor. Estonian experts ranked quality third. According to them, information transparency is a more important factor. In fact, quality and transparency can be synonyms: In the absence of transparency, information may not be of good quality.

Six subfactors of a bank's characteristics factor were analysed. They are as follows: Competence, integrity, goodwill, shared values, reputation, and image. All experts' individual comparison matrices satisfied the compatibility condition and, therefore, did not require modification. The compatibility ratio and lambda $(\lambda)$ met the conditions set (see Table 7). It can be concluded that the aggregate experts' assessments may be used in the general summary of results. The consensus index was greater than 80 per cent in all the analysed countries (see Table 7). The criteria used for the assessment of expert opinions were satisfied, making it possible to analyse the weights assigned to aggregated subfactors (see Table 7).

Table 7. Weights of bank's characteristics subfactors (authors' calculations, based on experts' assessment).

\begin{tabular}{cccc}
\hline \multirow{2}{*}{ Subfactor } & \multicolumn{3}{c}{ Weight (Rank) } \\
\cline { 2 - 4 } & LT & LV & EE \\
\hline Competence & $0.149(4)$ & $0.208(1)$ & $0.161(4)$ \\
Integrity & $0.224(2)$ & $0.156(4)$ & $0.205(2)$ \\
Goodwill & $0.112(5)$ & $0.125(5)$ & $0.115(5)$ \\
Shared values & $0.108(6)$ & $0.114(6)$ & $0.106(6)$ \\
Reputation & $0.247(1)$ & $0.206(2)$ & $0.216(1)$ \\
Image & $0.160(3)$ & $0.192(3)$ & $0.196(3)$ \\
\hline \multicolumn{4}{c}{ Technical Parameters } \\
\hline$\lambda ; \mathrm{CR} ; \mathrm{S}^{*}$ & $6.0280 .004 ; 81.31 \%$ & $6.050 ; 0.008 ; 89.3 \% ;$ & $6.026 ; 0.004 ; 87.1 \%$ \\
\hline
\end{tabular}

Lithuanian and Estonian experts agreed that the main subfactor of a bank's characteristics is the bank's reputation (see Table 7). Undoubtedly, reputation is a factor that can help to achieve higher profitability because with a good reputation, commercial banks can attract more customers. Customers who chose a bank based on its reputation feel greater confidence in the bank; hence, reputation directly promotes consumer confidence in banking services growth. In addition, Lithuanian and Estonian experts deemed integrity an important subfactor. It is a commercial bank interest in the client's well-being. Commercial banks are interested in making the appropriate environment because only in this case will users feel comfortable and trust the growth. Unlike Lithuanian and Estonian experts, Latvian experts provided the second position for reputation, and the fourth position for integrity and the first place gave for competence. Undoubtedly, service staff competence is essential in solving everyday customer problems associated with internet banking. Thus, competence as integrity is important to create the proper environment for users; however, Lithuanian and Estonian experts' assessment was similar, and they only gave the fourth position to competence. Baltic experts ranked the image of a commercial bank third. Actually, the image gives organisations such as commercial banks a competitive advantage in an environment where any other organisations offering similar services as commercial banks act.

While analysing banks' websites, three subfactors were distinguished: A website's security, privacy, and fairness. The aggregated matrix satisfied all the conditions; hence, it could be used in order to analyse the aggregated weights of the subfactors.

The consensus index was greater than 74 per cent for all the examined countries (see Table 8).

Experts from all Baltic countries agreed that security is the most important subfactor concerning websites (see Table 8). Security is associated with the technical aspects of internet use, such as the technically safe use of the website, password security, information storage, etc. Experts ranked privacy second. Individual customers understand privacy as an opportunity to use online bank services 
confidentially, i.e., not disclosing, for instance, payment history or the amount of money on the account to third parties. Thus, security and privacy are concepts, adjacent to each other, which could be seen from the ranks designated by experts. Fairness was ranked third. Actually, customers can only feel secure when the bank is fair to its consumers. What is more, privacy cannot be reached without fairness, because the client ought to be assured of the bank's fairness. In other words, the bank could make its clients feel secure and private only if it is fair.

Table 8. Weights of website subfactors (authors' calculations, based on expert evaluation).

\begin{tabular}{cccc}
\hline \multirow{2}{*}{ Subfactor } & \multicolumn{3}{c}{ Weight (Rank) } \\
\cline { 2 - 4 } & LT & LV & EE \\
\hline Security & $0.478(1)$ & $0.348(1)$ & $0.430(1)$ \\
Privacy & $0.319(2)$ & $0.310(2)$ & $0.219(2)$ \\
Fairness & $0.203(3)$ & $0.343(3)$ & $0.351(3)$ \\
\hline \multicolumn{4}{c}{ Technical Parameters } \\
\hline$\lambda ; \mathrm{CR}^{*} \mathrm{~S}^{*}$ & $3.008 ; 0.008 ; 74.1 \%$ & $3.003 ; 0.003 ; 83.3 \% ;$ & $3.015 ; 0.016 ; 84.4 \%$ \\
\hline
\end{tabular}

Examining e-banking system factors, four subfactors were picked: Ease of use, perceived benefits, satisfaction with the system, and internal motivation of the customer. After analysing pairwise comparison matrices, the aggregated matrix was developed, where the consistency ratio and lambda $(\lambda)$ met the conditions (see Table 9), meaning that the experts' evaluations were accurate. What is more, the consensus index was higher than $68 \%$ in all three countries.

Table 9. Weights of e-banking system subfactors (authors' calculations, based on experts' assessment).

\begin{tabular}{cccc}
\hline \multirow{2}{*}{ Subfactor } & \multicolumn{3}{c}{ Weight (Rank) } \\
\cline { 2 - 4 } & LT & LV & EE \\
\hline Ease of use & $0.290(2)$ & $0.267(2)$ & $0.315(1)$ \\
Perceived benefits & $0.293(1)$ & $0.286(1)$ & $0.303(2)$ \\
Satisfaction with the system & $0.209(3)$ & $0.238(3)$ & $0.217(3)$ \\
Internal customers' motivation & $0.208(4)$ & $0.209(4)$ & $0.164(4)$ \\
\hline & Technical Parameters \\
\hline$\lambda ;$ CR; $^{*}$ & $4.016 ; 0.006 ; 86.1 \%$ & $4.003 ; 0.001 ; 90.9 \%$ & $4.005 ; 0.002 ; 87.0 \%$ \\
\hline
\end{tabular}

Experts from Lithuania and Latvia ranked perceived usefulness first (see Table 9). In reality, customers should fully understand e-banking systems' benefits, such as time-saving, management of personal finances, etc. Estonian experts ranked ease of use first and perceived benefits second, while Lithuanian and Latvian experts considered ease of use second. In fact, the differences between the weights of first and second positions are minor; hence, it could be stated that these two subfactors are the most important in e-banking trust formation.

The tables presented above (see Tables 6-9) provide the local weights of the subfactors. The global values of the subfactors ought to be calculated in order to estimate the impact of each subfactor on trust in internet banking. The subfactors' local weights should be multiplied by the weight of the corresponding factor to get global values. The global weights of the subfactors are presented in the table below (see Table 10).

The most important factors, determining customer trust in online banking in Lithuania, are security (0.98); information reliability (0.96); perceived usefulness of the e-banking system (0.95); and ease of use of the e-banking system (0.94) (see Table 10). Latvian experts set the maximum weight for security at 0.123 ; for fairness second at 0.121 ; privacy and perceived usefulness of the e-banking system according to experts from Latvia are nonetheless important, as their weights were 0.110 and 0.105, respectively. According to Estonian experts, security was also ranked high and prioritised, and 
its weight reached 0.141; fairness and ease of use of the e-banking system second and third, respectively (0.115 and 0.102), and perceived usefulness of the e-banking system forth (0.098).

Table 10. Global weights of subfactors influencing trust in internet banking (authors' calculations, based on experts' assessment).

\begin{tabular}{cccc}
\hline Subfactors & LT & LV & EE \\
\hline Information transparency & 0.052 & 0.033 & 0.055 \\
Information quality & 0.058 & 0.038 & 0.051 \\
Information reliability & $0.096(2)$ & 0.041 & 0.085 \\
Competence of bank's employees & 0.039 & 0.035 & 0.026 \\
Integrity & 0.059 & 0.026 & 0.033 \\
Goodwill of bank's employees & 0.031 & 0.021 & 0.018 \\
Shared values of a bank and a customer & 0.029 & 0.019 & 0.017 \\
Reputation of a bank & 0.065 & 0.034 & 0.034 \\
Image of a bank & 0.042 & 0.032 & 0.031 \\
Security & $0.098(1)$ & $0.123(1)$ & $0.141(1)$ \\
Privacy & 0.065 & $0.110(3)$ & 0.072 \\
Fairness & 0.042 & $0.121(2)$ & $0.115(2)$ \\
Ease of use of e-banking system & $0.094(4)$ & 0.098 & $0.102(3)$ \\
Perceived usefulness of e-banking system & $0.095(3)$ & $0.105(4)$ & $0.098(4)$ \\
Satisfaction with e-banking system & 0.068 & 0.087 & 0.069 \\
Internal customers' motivation to use e-banking system & 0.067 & 0.077 & 0.053 \\
\hline
\end{tabular}

Lithuanian experts' opinion on the fairness differed from Latvian and Estonian experts' point of view. Results showed that in the case of Latvia and Estonia, fairness was one of the key subfactors affecting individual clients' trust in internet banking, while Lithuanian experts did not give this subfactor such importance. Information reliability was less critical for Latvian than for Lithuanian and Estonian experts. What is more, privacy was a much more important subfactor for Latvian than for Lithuanian and Estonian experts. Nevertheless, experts from all countries assessed security as the most important subfactor.

Taking into consideration the overall results of the resident and expert surveys, banks' decision-makers should note the following:

- In Latvia, the e-banking system and website are the most important;

- In Lithuania, the opinion of residents and exporters differs; thus, it is important to reflect on information, the bank, and the e-banking system;

- Estonian residents and experts also highlighted different criteria-the bank, website, and e-banking system;

For the facilitation and improvement of these factors, the following measures are significant:

- In Latvia, for the development of the e-banking system, perceived usefulness is the most important and for the promotion of the website, security;

- In Lithuania, the reliability of information, reputation of the bank, and perceived usefulness of the e-banking system should be inspiring;

- In Estonia, it is important to stress on the reputation of the bank, security of the website, and the ease of use of the e-banking system.

This research provides a meaningful conceptual contribution and offers important and influential practical insights. The first one includes a complex multidimensional criterion of trust. The testing of the highlighted factors allows to ascertain the most important factors in all analysed countries. Notwithstanding the fact that the history and mentality of all three Baltic States seems to be similar, the results differed. In addition, in all three countries, the same Scandinavian banks own the largest market share. Consequently, practical insights will guide decision-makers as to which particular elements of fair treatment have the most significant impact on trust in internet banking. 


\section{Conclusions}

For a better understanding of what drives customers to use internet-banking services, we analysed trust as the most essential element. As it is impossible to examine all the factors affecting users' trust in internet banking, the factors were grouped into four factors (information; the bank; website; e-banking system) and their subfactors. A respondents' survey (questionnaire) and expert evaluation method were used for data collecting and a pairwise comparison method for ranking the factors and their subfactors. The results of the respondents' survey were obtained using logistic regression. Summarising the results of the logistic regression analysis, it could be noted that the factors that help to increase the probability of individual customers' trust in internet banking differ in the analysed states: In Lithuania-information, in Latvia-website, and in Estonia-the bank.

The outcomes of the experts' pairwise comparison were generated using the analytic hierarchy process (AHP), based on a balanced scale. The inquiry made in the Baltic States showed that Lithuanian and Latvian experts highlighted the electronic banking system as a factor having the most significant impact on confidence in internet banking. While Estonian experts ranked the website first, however, the difference between this factor and e-banking is minimal, so it can be said that they are almost equivalent.

Subfactors were weighted locally and globally, and only the experts assessed them. The assessment of local weights showed that reliability is the most important subfactor of the information factor, and experts of all the countries ranked it first. One of the main subfactors of the bank is a bank's reputation, assessed by Lithuanian and Estonian experts, and competence by Latvian experts. Experts from all the countries agreed that security is the most critical subfactor when talking about the banks' website. Lithuanian and Latvian experts ranked perceived benefits first when assessing the e-banking system factor (ease of use to the second), while Estonian experts ranked ease of use first (perceived benefits second). As these differences are minor, it could be stated that these two subfactors are the most important in e-banking system trust formation.

According to the global weights, the most important subfactor influencing trust in internet banking in all the countries was security.

In the era of digitalisation, when banks move to various forms of electronic services, the emphasised factors influencing the level of customers' trust in internet banking could be helpful for decision-makers. Definitely, the results in other countries could substantially differ. Even though all three analysed countries have a similar history and geography and seem to have a related mentality, the trust-driving factors vary. For further investigation, it would be useful to stress on the factors that have a negative impact on trust-building.

Author Contributions: V.S. and D.J. worked on the idea of the research. D.J. was responsible for scientific literature review, visualization, research results interpretation, conclusion preparation. V.S. was responsible for research design, methodology, data collection and analysis, validation of the research results.

Funding: This research received no external funding.

Conflicts of Interest: The authors declare no conflict of interest.

\section{Appendix A}

Table A1. Experts' competence coefficients.

\begin{tabular}{cccccc}
\hline Expert Code & Coefficient & Expert Code & Coefficient & Expert Code & Coefficient \\
\hline$E_{\mathrm{LT} 1}$ & 0.142 & $\mathrm{E}_{\mathrm{LV} 1}$ & 0.136 & $\mathrm{E}_{\mathrm{EE} 1}$ & 0.139 \\
$\mathrm{E}_{\mathrm{LT} 2}$ & 0.152 & $\mathrm{E}_{\mathrm{LV} 2}$ & 0.141 & $\mathrm{E}_{\mathrm{EE} 2}$ & 0.138 \\
$\mathrm{E}_{\mathrm{LT} 3}$ & 0.139 & $\mathrm{E}_{\mathrm{LV} 3}$ & 0.145 & $\mathrm{E}_{\mathrm{EE} 3}$ & 0.143 \\
$\mathrm{E}_{\mathrm{LT} 4}$ & 0.139 & $\mathrm{E}_{\mathrm{LV} 4}$ & 0.142 & $\mathrm{E}_{\mathrm{EE} 4}$ & 0.148 \\
$\mathrm{E}_{\mathrm{LT} 5}$ & 0.143 & $\mathrm{E}_{\mathrm{LV} 5}$ & 0.139 & $\mathrm{E}_{\mathrm{EE} 5}$ & 0.144 \\
$\mathrm{E}_{\mathrm{LT} 6}$ & 0.149 & $\mathrm{E}_{\mathrm{LV} 6}$ & 0.151 & $\mathrm{E}_{\mathrm{EE} 6}$ & 0.143 \\
$\mathrm{E}_{\mathrm{LT} 7}$ & 0.136 & $\mathrm{E}_{\mathrm{LV} 7}$ & 0.146 & $\mathrm{E}_{\mathrm{EE} 7}$ & 0.145 \\
\hline
\end{tabular}




\section{References}

1. Siddik, M.N.A.; Sun, G.; Kabira, S.; Shanmugan, J.; Yanjuan, C. Impacts of E-banking on Performance of Banks in a Developing Economy: Empirical Evidence from Bangladesh. J. Bus. Econ. Manag. 2016, 17, 1066-1080. [CrossRef]

2. Keskar, M.Y.; Pandey, N. Internet banking: A review (2002-2016). J. Internet Commer. 2018, 17, $310-323$. [CrossRef]

3. Szopiński, T.S. Factors affecting the adoption of online banking in Poland. J. Bus. Res. 2016, 69, 4763-4768. [CrossRef]

4. Montazemi, A.R.; Qahri-Saremi, H. Factors affecting adoption of online banking: A meta-analytic structural equation modeling study. Inf. Manag. 2015, 52, 210-226. [CrossRef]

5. Boateng, H.; Adam, D.R.; Okoe, A.F.; Anning-Dorson, T. Assessing the determinants of internet banking adoption intentions: A social cognitive theory perspective. Comput. Hum. Behav. 2016, 65, 468-478. [CrossRef]

6. Damghanian, H.; Zarei, A.; Kojuri, M.A.S. Impact of Perceived Security on Trust, Perceived Risk, and Acceptance of Online Banking in Iran. J. Internet Commer. 2016, 15, 214-238. [CrossRef]

7. Ben Mansour, K. An analysis of business' acceptance of internet banking: An integration of e-trust to the TAM. J. Bus. Ind. Mark. 2016, 31, 982-994. [CrossRef]

8. Marafon, D.L.; Basso, K.; Espartel, L.B.; de Barcellos, M.D.; Rech, E. Perceived risk and intention to use internet banking. Int. J. Bank Mark. 2018, 36, 277-289. [CrossRef]

9. Yiga, C.; Cha, K.J. Toward understanding the importance of trust in influencing Internet banking adoption in Uganda. Inf. Dev. 2016, 32, 622-636. [CrossRef]

10. Fungáčová, Z.; Hasan, I.; Weill, L. Trust in banks. J. Econ. Behav. Organ. 2017. [CrossRef]

11. Alghamdi, A.; Elbeltagi, I.; Elsetouhi, A.; Haddoud, M.Y. Antecedents of continuance intention of using Internet banking in Saudi Arabia: A new integrated model. Strateg. Chang. 2018, 27, 231-243. [CrossRef]

12. Sikdar, P.; Kumar, A.; Makkad, M. Online banking adoption. Int. J. Bank Mark. 2015, 33, 760-785. [CrossRef]

13. Vejačka, M.; Štofa, T. Influence of security and trust on electronic banking adoption in Slovakia. E+M Ekon. a Manag. 2017, 20, 135-150. [CrossRef]

14. Aldás-Manzano, J.; Lassala-Navarré, C.; Ruiz-Mafé, C.; Sanz-Blas, S. Key drivers of internet banking services use. Online Inf. Rev. 2009, 33, 672-695. [CrossRef]

15. Bashir, I.; Madhavaiah, C. Determinants of Young Consumers' Intention to Use Internet Banking Services in India. Vis. J. Bus. Perspect. 2014, 18, 153-163. [CrossRef]

16. Casaló, L.V.; Flavián, C.; Guinalíu, M. The role of satisfaction and website usability in developing customer loyalty and positive word-of-mouth in the e-banking services. Int. J. Bank Mark. 2008, 26, 399-417. [CrossRef]

17. Ong, C.-S.; Lin, Y.-L. Security, Risk, and Trust in Individuals' Internet Banking Adoption: An Integrated Model. Int. J. Electron. Commer. Stud. 2015, 6, 343-356. [CrossRef]

18. Sehra, S.K.; Brar, Y.S.; Kaur, N. Multi Criteria Decision Making Approach for Selecting Effort Estimation Model. Int. J. Comput. Appl. 2012, 39, 10-17.

19. Suvanto, H. Constructing a typology of trust in asymmetrical food business relationships. Br. Food J. 2012, 114, 926-943. [CrossRef]

20. Thakur, R. What keeps mobile banking customers loyal? Int. J. Bank Mark. 2014, 32, 628-646. [CrossRef]

21. Chong, A.Ye.; Ooi, K.; Lin, B.; Tan, B. Online banking adoption: An empirical analysis. Int. J. Bank Mark. 2010, 28, 267-287. [CrossRef]

22. Özkan, S.; Bindusara, G.; Hackney, R. Facilitating the adoption of e-payment systems: Theoretical constructs and empirical analysis. J. Enterp. Inf. Manag. 2010, 23, 305-325. [CrossRef]

23. Yeh, Y.S.; Li, Y. Building trust in m-commerce: Contributions from quality and satisfaction. Online Inf. Rev. 2009, 33, 1066-1086.

24. Yap, K.B.; Wong, D.H.; Loh, C.; Bak, R. Offline and online banking-Where to draw the line when building trust in e-banking? Int. J. Bank Mark. 2010, 28, 27-46. [CrossRef]

25. Loureiro, S.M.C.; Miranda, F.J.; Breazeale, M. Who needs delight? J. Serv. Manag. 2014, 25, $101-124$. [CrossRef] 
26. Butt, M.M.; Aftab, M. Incorporating attitude towards Halal banking in an integrated service quality, satisfaction, trust and loyalty model in online Islamic banking context. Int. J. Bank Mark. 2013, 31, 6-23. [CrossRef]

27. Akhlaq, A.; Ahmed, E. The effect of motivation on trust in the acceptance of internet banking in a low income country. Int. J. Bank Mark. 2013, 31, 115-125. [CrossRef]

28. Zhu, Y.; Chen, H. Service fairness and customer satisfaction in internet banking. Internet Res. 2012, 22, 482-498. [CrossRef]

29. Liébana-Cabanillas, F.; Muñoz-Leiva, F.; Rejón-Guardia, F. The determinants of satisfaction with e-banking. Ind. Manag. Data Syst. 2013, 113, 750-767. [CrossRef]

30. Yu, P.L.; Balaji, M.S.; Khong, K.W. Building trust in internet banking: A trustworthiness perspective. Ind. Manag. Data Syst. 2015, 115, 235-252. [CrossRef]

31. Roy, S.K.; Balaji, M.S.; Kesharwani, A.; Sekhon, H. Predicting Internet banking adoption in India: A perceived risk perspective. J. Strateg. Mark. 2017, 25, 418-438. [CrossRef]

32. Zhao, A.L.; Koenig-Lewis, N.; Hanmer-Lloyd, S.; Ward, P. Adoption of internet banking services in China: Is it all about trust? Int. J. Bank Mark. 2010, 28, 7-26. [CrossRef]

33. Siriluck, R.; Speece, M. The impact of web-based service on switching cost. In Proceedings of the 7th International Conference on Electronic commerce-ICEC '05, Xi'an, China, 15-17 August 2005; p. 11.

34. Susanto, A.; Lee, H.; Zo, H.; Ciganek, A.P. User acceptance of Internet banking in Indonesia: Initial trust formation. Inf. Dev. 2013, 29, 309-322. [CrossRef]

35. Patel, K.J.; Patel, H.J. Adoption of internet banking services in Gujarat. Int. J. Bank Mark. 2018, 36, 147-169. [CrossRef]

36. Namahoot, K.S.; Laohavichien, T. Assessing the intentions to use internet banking. Int. J. Bank Mark. 2018, 36, 256-276. [CrossRef]

37. Lee, S.P.; Moghavvemi, S. The dimension of service quality and its impact on customer satisfaction, trust, and loyalty: A case of Malaysian banks. Asian J. Bus. Account. 2015, 8, 91-121.

38. Chemingui, H.; Lallouna, H.B. Resistance, motivations, trust and intention to use mobile financial services. Int. J. Bank Mark. 2013, 31, 574-592. [CrossRef]

39. Pandey, P.; Mayya, S.; Joshi, H.G. Internet Banking: A Survey on New Approach to Banking and Its Adoption Among Urban Conglomerates of Coastal Karnataka. Adv. Sci. Lett. 2017, 23, 1960-1963. [CrossRef]

40. Kaabachi, S.; Mrad, S.B.; Petrescu, M. Consumer initial trust toward internet-only banks in France. Int. J. Bank Mark. 2017, 35, 903-924. [CrossRef]

41. Hajiheydari, N.; Ashkani, M. Mobile application user behavior in the developing countries: A survey in Iran. Inf. Syst. 2018, 77, 22-33. [CrossRef]

42. Sekhon, H.; Roy, S.; Shergill, G.; Pritchard, A. Modelling trust in service relationships: A transnational perspective. J. Serv. Mark. 2013, 27, 76-86. [CrossRef]

43. Skvarciany, V.; Jurevičienè, D. Factors Influencing Customer Trust in Mobile Banking: Case of Latvia. Econ. Cult. 2017, 14, 69-76. [CrossRef]

44. Libby, R.; Blashfield, R.K. Performance of a composite as a function of the number of judges. Organ. Behav. Hum. Perform. 1978, 21, 121-129. [CrossRef]

45. Augustinaitis, A.; Rudzkienè, V.; Petrauskas, R.A.; Dagytė, I.; Martinaitytè, E.; Leichteris, E.; Malinauskienė, E.; Višnevska, V.; Žilionienè, I. Lietuvos e. Valdžios Gairès: Ateities İžvalgu Tyrimas; Mykolas Romeris University: Vilnius, Lithuania, 2009.

46. Vale, L.; Silcock, J.; Rawles, J. General practice community. BMJ 1997, 314, 570-572. [CrossRef] [PubMed]

47. Dalati, S.; Alchach, H. The Effect of Leader Trust and Knowledge Sharing on Staff Satisfaction at Work: Investigations of Universities in Syria. Bus. Manag. Educ. 2018, 16, 190-205. [CrossRef]

48. Niva, M.; Jallinoja, P. Taking a Stand through Food Choices? Characteristics of Political Food Consumption and Consumers in Finland. Ecol. Econ. 2018, 154, 349-360. [CrossRef]

49. Xie, Y.; Xue, W.; Li, L.; Wang, A.; Chen, Y.; Zheng, Q.; Wang, Y.; Li, X. Leadership style and innovation atmosphere in enterprises: An empirical study. Technol. Forecast. Soc. Chang. 2018, 135, 257-265. [CrossRef]

50. Smart, A.; Harrison, E. The under-representation of minority ethnic groups in UK medical research. Ethn. Health 2017, 22, 65-82. [CrossRef]

51. De Menezes, F.S.; Liska, G.R.; Cirillo, M.A.; Vivanco, M.J.F. Data classification with binary response through the Boosting algorithm and logistic regression. Expert Syst. Appl. 2017, 69, 62-73. [CrossRef] 
52. Pandya, D.H.; Upadhyay, S.H.; Harsha, S.P. Fault diagnosis of rolling element bearing by using multinomial logistic regression and wavelet packet transform. Soft Comput. 2014, 18, 255-266. [CrossRef]

53. Nagelkerke, N.J.D. A note on a general definition of the coefficient of determination. Biometrika 1991, 78, 691-692. [CrossRef]

54. Peng, C.-Y.J.; Lee, K.L.; Ingersoll, G.M. An Introduction to Logistic Regression Analysis and Reporting. J. Educ. Res. 2002, 96, 3-14. [CrossRef]

55. Awa, H.O.; Ukoha, O.; Emecheta, B.C. Using T-O-E theoretical framework to study the adoption of ERP solution. Cogent Bus. Manag. 2016, 3, 1196571. [CrossRef]

56. Chen, C.; Zhang, J. Exploring background risk factors for fatigue crashes involving truck drivers on regional roadway networks: A case control study in Jiangxi and Shaanxi, China. SpringerPlus 2016, 5, 582. [CrossRef] [PubMed]

57. Zenzerović, R.; Valić-Vale, M. Diagnosing companies in financial difficulty based on the auditor's report. Croat. Oper. Res. Rev. 2016, 7, 147-158. [CrossRef]

58. Lumley, T. Pseudo- R 2 statistics under complex sampling. Aust. N. Z. J. Stat. 2017, 59, 187-194. [CrossRef]

59. Salo, A.A.; Hämäläinen, R.P. On the measurement of preferences in the analytic hierarchy process. J. Multi-Criteria Decis. Anal. 1997, 6, 309-319. [CrossRef]

60. Saaty, T.L. Decision Making for Leaders: The Analytic Hierarchy Process for Decisions in a Complex World, 3rd ed.; RWS Publications: Pittshburg, PA, USA, 2012.

61. Van Laarhoven, P.J.M.; Pedrycz, W. A fuzzy extension of Saaty's priority theory. Fuzzy Sets Syst. 1983, 11, 229-241. [CrossRef]

62. Franek, J.; Kresta, A. Judgment Scales and Consistency Measure in AHP. Procedia Econ. Financ. 2014, 12, 164-173. [CrossRef]

63. Goepel, K.D. Implementing the Analytic Hierarchy Process as a Standard Method for Multi-Criteria Decision Making in Corporate Enterprises-A New AHP Excel Template with Multiple Inputs. Proc. Int. Symp. Anal. Hierarchy Process 2013, 1-10. [CrossRef]

64. Skvarciany, V.; Jurevičienè, D. "Mano Apklausa”, Survey Trust in commercial banks. 2018. Available online: http:/ / manoapklausa.lt/apklausa/740404051/ (accessed on 2 September 2018).

(c) 2018 by the authors. Licensee MDPI, Basel, Switzerland. This article is an open access article distributed under the terms and conditions of the Creative Commons Attribution (CC BY) license (http:/ / creativecommons.org/licenses/by/4.0/). 